\title{
A clinical case report of cystic fibrosis and liver cirrhosis in a child
}

\author{
V. A. Klymenko ${ }^{1}$, 0. V. Piontkovska ${ }^{2}$, 0. V. Pasichnyk ${ }^{2}$, N. M. Drobova ${ }^{1}$, K. O. Yanovska ${ }^{1}$, \\ S. I. Bevz², N. T. Sindieieva ${ }^{2}$ \\ ${ }^{1}$ Kharkiv National Medical University, Ukraine, ${ }^{2}$ Kharkiv Regional Clinical Children's Hospital No. 1, Ukraine
}

Purpose. To analyze the history of a child with cystic fibrosis (CF) and liver cirrhosis.

Results of research. This clinical case report demonstrates the course of CF in a patient with a severe CFTR mutation delF508. The disease had severe course, mostly due to hepato-renal disorders.

From birth the child had a poor appetite, insufficient weight gain. A cough bothered the child from age of three months, and then pneumonia was diagnosed with a protracted course. CF was diagnosed by positive sweat chloride test $(85 / 107 \mathrm{mmol} / \mathrm{L})$ and clinical manifestations at the age of eight months.

CFTR mutation delF508 was found during genetic testing. The patient had chronic airways colonization with S. aureus and $P$. aeruginosa. At 1 year of age the child was infected by $S$. aureus, at 6 year of age - P. aeruginosa. The child received pathogenetic treatment including inhaled antibiotic therapy (tobramycin, colistin). The child constantly received the replacement enzyme therapy, hepatoprotective drugs and multivitamins. Antibiotic therapy was prescribed only for bronchopulmonary exacerbation.

At 8 years of age the biliary cirrhosis, portal hypertension and splenomegaly $(+6.0 \mathrm{~cm})$ were found. Type 1 diabetes mellitus was diagnosed at 9 years of age. The child's condition worsened progressively mostly due to hepato-renal disorders. The child needed permanent hospital care.

The last patient's hospitalization lasted for 85 bed-days, including 52 days in the Department of Anesthesiology and Intensive Care because of the condition worsening due to multiple organ dysfunction syndrome that caused death at 17 years of age.

Conclusions. This clinical case report demonstrates the course and outcomes of cystic fibrosis with severe CFTR mutation delF508 and cirrhosis.

\section{Кмінічний випадок дитини з муковісцидозом і цирозом печінки}

\section{В. А. Клименко, О. В. Піонтковська, О. В. Пасічник, Н. М. Аробова, К. О. Яновська, С. І. Бевз, Н. Т. Сіндєєва}

Мета роботи - аналіз історії життя дитини з муковісцидозом (MB) і цирозом печінки.

Результати. Клінічний випадок демонструє перебіг MB у хворого з тяжкою мутацією delF508 гена MB. Захворювання мало тяжкий перебіг здебільшого через гепато-ренальні порушення.

Від народження в дитини відзначали поганий апетит, недостатнє додавання ваги. На третьому тижні життя з'явилися кашель і підвищення температури тіла, з приводу чого дитину госпіталізовано у стаціонар. Діагностували пневмонію, яка мала затяжний перебіг. На підставі клінічних ознак запідозрили захворювання на МВ. Діагноз остаточно підтверджений у віці 8 місяців після дворазового позитивного пілокарпінового тесту (85/107 ммоль/л). Під час генетичного дослідження виявлена тяжка мутація delF508 гена MB (CFTR) у компаунді з неідентифрікованою мутацією. Хронічна колонізація трахео-бронхіального дерева інфекцією Staphylococcus aureus (з 1 року) та Pseudomonas aeruginosa (з 6 років), з приводу чого дитина отримувала антибактеріальні препарати з антистафілококовою та антисиньогнійною активністю, зокрема інгаляційні (тобраміцин, колістин).

Дитина постійно отримувала замісну ферментну терапію, гепатопротектори, муколітики, вітаміни. Антибактеріальну терапію призначали при загостреннях бронхо-легеневого запального процесу. У 8 років з'явилися скарги на спрагу, визначили поліурію. Діагностували цукровий діабет 1 типу. 39 років визначали ознаки цирозу печінки, портальної гіпертензії, збільшення селезінки (+6 см). Стан дитини прогресивно погіршувався, переважно через гепато-ренальну недостатність. Дитина майже не покидала стаціонар.

Під час останньої госпіталізації дитина провела в лікарні 85 ліжко-днів, 52 з них у відділенні анестезіології та інтенсивної терапії. Незважаючи на всі заходи, вжиті згідно з протоколами лікування, стан дитини погіршувався через розвиток синдрому поліорганної недостатності, що й стало причиною смерті дитини у віці 17 років.

Висновки. Описано особливості клінічного перебігу MB у хворого з тяжкою мутацією delF508 і цирозом печінки.
Key words: children, cystic fibrosis liver, cirrhosis.

\section{Zaporozhye} medical journa 2018; 20 (5), 739-742 Dol: 10.14739/2310-1210 2018.5.141713

E-mail: dn88n5@gmail.com
Ключові слова: муковісциАОз, Аіти, цироз печінки.

Запорізький медичний журнал. - 2018. T. 20, № 5(110). -

C. $739-742$

\section{Клинический случай ребенка с муковисцидозом и циррозом печени}

\section{В. А. Клименко, О. В. Пионтковская, Е. В. Пасичник, Н. Н. Аробова, Е. А. Яновская, С. И. Бевз, Н. Т. Синдеева}

Цель работы - анализ истории жизни ребенка с муковисцидозом (MB) и циррозом печени.

Результаты. Клинический случай демонстрирует течение MB у больного с тяжелой мутацией delF508. Заболевание имело тяжелое течение в основном за счет гепато-ренальных нарушений.

С рождения у ребенка отмечали плохой аппетит, недостаточную прибавку веса. На третьей неделе жизни появились кашель и повышение температуры тела, по поводу чего ребенка госпитализировали в стационар. Диагностировали пневмонию,

Ключевые слова: муковисциАОЗ, Аети, цирроз печени.

Запорожский медицинский журнал. - 2018. T. 20, № 5(110). C. 739-742 
которая имела затяжное течение. На основании клинических признаков заподозрен МВ. Диагноз окончательно подтвержден в возрасте 8 месяцев после двукратного положительного пилокарпинового теста (85/107 ммоль/л). При генетическом исследовании обнаружена тяжелая мутация delF508 гена MB (CFTR) в компаунде с неидентифицированной мутацией. Хроническая колонизация трахео-бронхиального дерева инфекцией Staphylococcus aureus (с 1 года) и Pseudomonas aeruginosa (с 6 лет), по поводу чего ребенок получал антибактериальные препараты с антистафилококковой и антисинегнойной активностью, в том числе ингаляционные (тобрамицин, колистин).

Ребенок постоянно получал заместительную ферментную терапию, гепатопротекторы, муколитики, витаминные препараты. Антибактериальную терапию назначали при обострениях бронхо-легочного воспалительного процесса. В 8 лет появились жалобы на жажду, отмечена полиурия. Диагностирован сахарный диабет 1 типа. С 9 лет отмечены признаки цирроза печени, портальной гипертензии, увеличение селезенки (+6 см). Состояние ребенка прогрессивно ухудшалось, преимущественно за счет гепато-ренальной недостаточности. Ребенок практически не покидал стационар.

Во время последней госпитализации ребенок провел в больнице 85 койко-дней, 52 из них в отделении анестезиологии и интенсивной терапии. Несмотря на проведение всех мероприятий согласно протоколам лечения, состояние ухудшалось за счет развития синдрома полиорганной недостаточности, что и стало причиной смерти ребенка в возрасте 17 лет.

Выводы. Описаны особенности клинического течения MB у больного с тяжелой мутацией delF508 и циррозом печени.

\section{Introduction}

Cystic fibrosis (CF) is one of the most common hereditary multiple organ diseases characterized by the exocrine glands and vital organs insufficiency [3]. Along with the pulmonary system disorders the liver and pancreas pathology are essential among factors which determine the prognosis of a patient with CF [1]. CF is an important social problem all over the world, as it is accompanied by high mortality, early disability, the need for continuous treatment and active dispensary monitoring. In $1905 \mathrm{CF}$ was first described by Landsteiner, who observed two children with meconium obstruction and cystic changes in the pancreas. But the fate of these patients has fundamentally changed over the past 100 years. At the beginning of the 20th century, CF was diagnosed posthumously. Most patients died in the first year of life. Now the average life expectancy of these patients in the developed countries is about 35-37 years. In Ukraine, there is no official mortality statistics for $\mathrm{CF}$, but some authors report the average life expectancy of 12-14 years $[2,4-6]$.

The major cause of mortality (85-90 \%) among CF patients is pulmonary lesions [12]. In CF bronchopulmonary secretion is characterized by extremely high viscosity, which complicates its evacuation, causes complete or partial bronchi and bronchioles obstruction. This factor leads to the tracheobronchial colonization with pathogenic microorganisms (Staphylococcus aureus, Haemophilus influenzae, Pseudomonas aeruginosa, Stenotrophomonas maltophilia, Achromobacter xylosoxidans, Burkholderia cepacia complex etc.).

Liver lesion, such as liver cirrhosis, is the second most common cause of death associated with $\mathrm{CF}$ after bronchopulmonary complications $[1,8]$. Initial changes are local, but then begin to progress and lead to multilobular biliary liver cirrhosis, portal hypertension and all related pathological changes (deficiency of vitamin K-dependent clotting factors, splenomegaly, gastroesophageal variceal bleeding) [1].

According to various authors, $85-90 \%$ CF patients have exocrine pancreatic insufficiency [4]. The pancreas endocrine dysfunction is a matter of no small consequence. It manifests in secondary diabetes mellitus (DM) development. The DM problem in these patients is of great interest. The DM frequency in CF patients, according to various authors, varies from 2.5 to $32.0 \%$ and increases proportionally with the patients' age $[3,7,13]$. DM develops in
$15 \%$ of patients with CF and among patients older than 30 years this index is $50 \%$ [10]. Mechanisms of carbohydrate metabolism disorders in $\mathrm{CF}$ are significantly different from the pathogenetic mechanisms of type 1 and type $2 \mathrm{DM}$. Most authors are inclined to believe that DM in CF relates to a particular type [3,9]. In most cases cystic fibrosis-related diabetes is found in patients with severe mutations (for example, delF508, one of the most common mutations in the CF transmembrane regulator (CFTR) gene) $[1,11,14]$.

\section{Purpose}

To analyze the history of a child with CF and severe delF508 CFTR mutation.

\section{Materials and methods}

Clinical and paraclinical examinations of patient with $\mathrm{CF}$ according to the Order of MOH of Ukraine dated 19.03.2007, № 128 "On Approval of the Protocol of Medical Care for People with Cystic Fibrosis", Order of MOH of Ukraine dated 29.01.2013, № 59 "On Approval of Unified Clinical Protocols of Medical Care for Children with Diseases of the Digestive System". The study of the patient's medical documentation.

\section{Results}

The patient was a 16-year-old girl. She was admitted to the Kharkiv Regional Clinical Children's Hospital No 1 with complaints of cough, purulent sputum, shortness of breath, runny nose, sneezing and nosebleed. The condition was defined as severe due to cardiorespiratory disturbances, chronic pancreatic insufficiency, liver failure, portal hypertension, hemorrhagic syndrome, metabolic disorders.

It is known, that the child was prematurely born after 33 weeks of gestation by vaginal delivery with a birth weight of $2400 \mathrm{gm}$. Child's mother noticed her poor appetite from birth.

A cough bothered the child from age of three months, and then pneumonia was diagnosed with a protracted course. The child was discharged from the hospital recovered. The dry cough remained. Complaints of foul-smelling, bulky and greasy stool, abdominal distension appeared after discharge from the hospital. The child was referred for a medical genetic center, where she was diagnosed with CF based on positive sweat chloride test $(85 / 107 \mathrm{mmol} / \mathrm{L})$ and clinical manifestations at the age of eight months. 
The child received the replacement enzyme therapy by Creon, ursodesoxycholic acid, mucolytics and multivitamins as a basic treatment. Antibiotic therapy was prescribed only during the bronchopulmonary exacerbation (every 2-3 months).

Genotyping was performed at 6 years old (delF508). The patient was not carrier of other mutations studied (dell507, 1677delTA (located in exon 10); 621+1G-T, R117H (located in exon 4); R334W, R347P (located in exon 7); 1717-1G-A (located in intron 10); R553X, G551D, G542X (located in exon 11); P129S, W1282 (located in exon 20); N1303K (located in exon 21); CFTRdele2,3 (21kb)). Child's parents didn't make genetic testing for the CFTR mutations.

The patient had chronic colonization of airways with S. aureus and P. aeruginosa. At 1 year of age patient was infected with $S$. aureus, at 6 years of age $-P$. aeruginosa. The child received pathogenetic therapy including inhaled antibiotic therapy (tobramycin, colistin), but only during a bronchopulmonary exacerbation (because of these drugs expensiveness).

At 8 years of age the biliary cirrhosis, portal hypertension and splenomegaly $(+6,0 \mathrm{~cm})$ were found on routine examination. At 9 years of age type 1 diabetes mellitus was diagnosed.

The child's condition deteriorated. The frequency of bronchopulmonary exacerbation increased (once a month). The manifestations of cardiorespiratory, hepatorenal insufficiency, neurological disorders increased gradually. The child needed permanent hospital care. From 2014 year onwards the child received treatment in the Kharkiv Regional Clinical Children's Hospital No 1. The patient required hospitalization for 283 days during 2015, the last patient's hospitalization lasted for 85 bed-days, including 52 days in the Department of Anesthesiology and Intensive Care because of the condition worsening due to multiple organ dysfunction syndrome that caused death at 17 years of age.

\section{On examination}

Physical growth and development was poor. Weight was $32 \mathrm{~kg}$, height was $146 \mathrm{~cm}$. Body mass index (BMI) was $15.01 \mathrm{~kg} / \mathrm{m}^{2}$ (equivalent to $\mathrm{BMI}<10$ percentiles). Patient had pale dry skin, deformity of the fingers and fingernails (clubbed fingers and watch-glass nails). On the feet and legs there were areas of pigmentation and petechial rash. She had skin peeling of the feet, ecchymosis on the shoulders. Thoracic cage was cylindrical. Percussion sound was shortened in back basal areas, hyperresonant - in the upper and middle areas. Harsh breathing, moist small- and medium bubbling rales were detected during lung auscultation. Heart sounds were rhythmic, muffled. There were systolic murmurs in all auscultation areas. The abdomen was enlarged due to hepatomegaly $(+8.0 \mathrm{~cm})$, splenomegaly $(+15.0 \mathrm{~cm})$. Delayed puberty was diagnosed P1 Ax1 Ma1 Me1. Steatorrhea was present.

Her condition deteriorated gradually. The child could not walk because of severe cardiovascular insufficiency, polyneuropathy. Repeated tonic-clonic seizures, severe edema syndrome were developed, ascites (about 2.6 liters of fluid was removed from the abdominal cavity every day). She had the enlarged liver $(12 \mathrm{~cm})$, and spleen $(17 \mathrm{~cm})$. Signs of the portal hypertension and hemorrhagic syndrome (such as ecchymosis, scleral hemorrhage, periorbital ecchymosis) were aggravated.
The results of some laboratory studies were as follows: hemoglobin - $42 \mathrm{gr} / \mathrm{L}$, total protein $-47 \mathrm{gr} / \mathrm{L}$, C-reactive protein $-4+$, platelets $-30 \times 109 / \mathrm{L}$, urea $-18.8 \mathrm{mmol} / \mathrm{l}$, creatinine $-0.441 \mathrm{mmol} / \mathrm{L}$, glucose $-2.0-19.2 \mathrm{mmol} / \mathrm{L}$, residual nitrogen - $664 \mathrm{mg} / \mathrm{L}$, proteinuria $-0.2 \mathrm{~g} / \mathrm{L}$, glucosuria $-0.1 \mathrm{mmol} / \mathrm{L}$, oliguria.

The issue of splenectomy had been discussed repeatedly because of anemia and thrombocytopenia, but the severity of the CF course didn't allow the operation to be conducted.

All necessary types of therapy were used for treatment, such as antibacterial, bronchodilatory, anti-inflammatory, mucolytic, replacement enzyme therapy, gastroprotective, hepatoprotective, choleretic drugs, vitamins, insulin therapy, hemostatic drugs, drugs for pulmonary hypertension reduction, detoxification therapy and, blood transfusion. Hemodialysis wasn't possible because of hemorrhagic syndrome with severe thrombocytopenia. The child received constant supervision of a resuscitator, surgeon, pulmonologist, endocrinologist, hematologist, ophthalmologist, neurologist, gastroenterologist and otolaryngologist. Despite all the measures according to the treatment protocols, the child's condition worsened due to multiple organ dysfunction syndrome that caused death.

Pathologic-anatomic diagnosis. CF with pulmonary and intestinal manifestations, severe course. Bilateral mixed bronchiectasis. Chronic obstructive bronchitis. Chronic colonization of airways with Pseudomonas aeruginosa. Chronic cardiopulmonary disease. Chronic cor pulmonale. Moderate pulmonary hypertension. Chronic pancreatic insufficiency, severe course. Type 1 diabetes mellitus, severe course. Decompensated macronodular cirrhosis. Portal hypertension syndrome, bleeding from esophageal and stomach varices. Chronic gastroduodenitis. Ascites. Urolithiasis. Hypersplenism. Deficiency anemia. Metabolic encephalopathy. Multiple organ dysfunction syndrome.

\section{Discussion}

This clinical case demonstrates the course and outcomes of CF with severe CFTR-delF508 mutation, which is characterized by early development of diabetes mellitus (at 8 years of age), liver cirrhosis with progressive hepatic failure (at 9 years of age), hypersplenism. There are 43 children with $\mathrm{CF}$, who are observed in Kharkiv Regional Clinical Children's Hospital No. 1. Two patients suffer from diabetes mellitus that was diagnosed at 8 and 14 years of age. Liver cirrhosis is diagnosed in three patients.

The protocol of medical care to patients with CF, approved by the order of the Ministry of Health of Ukraine No. 723 dated July 15, 2016, indicates all necessary actions for the successful management of such patients (prophylactic antibiotics use, multiplicity of required examinations, transplantation of lungs and liver, etc.). All these measures are in line with international standards and, as the world experience shows, demonstrate their positive influence on the disease course. It is reflected in quality of life improvement and life expectancy increase in patients with CF.

The life expectancy of patients with CF in Ukraine is increasing. The number of such patients in each region increases. Therefore, not only the protocols implementation, but also the clinical cases of patients with CF analysis are essential in the medical care improving for these children. 


\section{Conclusions}

The features of the clinical course of CF in patients with CFTR-delF508 mutation are described. There were severe cardio-respiratory disturbances with pathology of the pancreas and liver, diabetes mellitus, development of hepatorenal insufficiency, metabolic encephalopathy, which caused an unfavorable prognosis of the disease.

Conflicts of Interest: authors have no conflict of interest to declare. Конфлікт інтересів: відсутній.

Information about authors:

Klymenko V. A., MD, PhD, DSc, Associate Professor, Head of Department of Fundamentals of Pediatrics No. 2, Kharkiv National Medical University, Ukraine.

Piontkovska O. V., MD, PhD, DSc, Professor, Head Physician of Kharkiv Regional Clinical Children's Hospital No. 1, Ukraine. Pasichnyk O. V., MD, Head of the Pulmonology Department, Kharkiv Regional Clinical Children's Hospital No. 1, Ukraine. Drobova N. M., MD, Postgraduate Student, Department of Fundamentals of Pediatrics No. 2, Kharkiv National Medical University, Ukraine.

Yanovska K. O., MD, PhD, Assistant, Department of Fundamentals of Pediatrics No. 2, Kharkiv National Medical University, Ukraine. Bevz S. I., MD, Head of the Department of Anesthesiology and Intensive Care, Kharkiv Regional Clinical Children's Hospital No. 1, Ukraine.

Sindieieva N. T., MD, Anesthesiologist and Intensive Care Physician, Department of Anesthesiology and Intensive Care, Kharkiv Regional Clinical Children's Hospital No. 1, Ukraine.

\section{Відомості про авторів:}

Клименко В. А., А-р меА. наук, доцент, зав. каф. пропедевтики педіатрії № 2, Харківський національний меАичний університет, україна.

Піонтковська О. В., А-р меА. наук, професор, головний лікар, КЗ303 "Обласна Аитяча клінічна мікарня № 1", м. Харків, Україна.

Пасічник О. В., зав. пульмонологічного відАілення, КЗОЗ "Обласна Аитяча кмінічна лікарня № 1", м. Харків, Україна. Аробова Н. М., аспірант каф. пропедевтики педіатрії № 2 Харківський національний медичний університет, Україна. Яновська К. О., канА. меА. наук, асистент каф. пропедевтики педіатрії № 2, Харківський національний медичний університет, Україна.

Бевз С. І., зав. відымення анестезіології та інтенсивної терапії, К303 "Обласна Аитяча клінічна лікарня №1", м. Харків, Україна. Сіндєєва Н. Т., лікар-анестезіолог відАілення анестезіології та інтенсивної терапії, КЗО3 "Обласна дитяча кмінічна мікарня № 1", м. Харків, Україна.

\section{Сведения об авторах:}

Клименко В. А., А-р меА. наук, Аоцент, зав. каф. пропедевтики педиатрии № 2, Харьковский национальный медицинский университет, Украина.

Пионтковская О. В., А-р меА. наук, профессор, главный врач, КУЗ “Областная Аетская клиническая больница № 1", г. Харьков, Украина.

Пасичник Е. В., зав. пульмонологическим отАелением, КУЗ "Областная детская клиническая больница № 1", г. Харьков, Украина.

Аробова Н. Н., аспирант каф. пропедевтики педиатрии № 2, Харьковский национальный медицинский университет, Украина. Яновская Е. А., канА. меА. наук, ассистент каф. пропедевтики педиатрии № 2, Харьковский национальный медицинский университет, Украина.

Бевз С. И., зав. отАелением анестезиологии и интенсивной терапии, КУЗ "Областная Аетская клиническая больница № 1", г. Харьков, Украина.

Синдеева Н. Т., врач-анестезиолог отАеления анестезиологии и интенсивной терапии, КУЗ "Областная детская кииническая больница № 1", г. Харьков, Украина.
Налійшла Ао реАакції / Received: 23.01.2018

Після Аоопрацювання / Revised: 08.02.2018

Прийнято Ао Аруку / Accepted: 19.02.2018

\section{References}

[1] Kapranov, N. I., \& Kashirskaya, N. Yu. (2014). Mukoviscidoz [Cystic fibrosis]. Moscow: Medpraktika. [in Russian].

[2] Manovitskaya, N. V., Borodina, G. L., \& Voytko, T. A. (2013). Dinamika klinicheskogo statusa vzroslykh pacientov s mukoviscidozom $\checkmark$ respublike Belarus' [Dynamics of clinical status of adult patients with mucoviscidosis in the Republic of Belarus]. Problemy zdorov'ya e'kologii, 2(36), 29-34. [in Russian].

[3] Самойленко, В. А., Бабаджанова, Г. Ю., Нагорный, А. Б., \& Красовский, С. А. (2013). Mukoviscidoz i sakharnyj diabet [Cystic fibrosis and diabetes]. Atmosfera. Pul'monologiya i allergologiya, 2, 32-37. [in Russian]

[4] Kashirskaya, N. Yu., Kapranov, N. I., Kusova, Z. A., \& Shelepneva, Z. A. (2010). Porazhenie podzheludochnoj zhelezy pri mukoviscidoze [The defeat of the pancreas in cystic fibrosis]. E'ksperemental'naya i klinicheskaya gastroe'nterologiya, 8, 98-103. [in Russian].

[5] Rohovyk, N. V. (2013). Metabolizm vitaminu E pry mukovistsydozi [The metabolism of vitamin E in cystic fibrosis]. Pediatriia, akusherstvo ta hinekolohiia, 76(3), 25-30. [in Ukrainian].

[6] Burgel, P. R., \& Bellis, G. (2015). Accuracy of modelling future trends in cystic fibrosis demography using the French Cystic Fibrosis Registry. Journal of Cystic Fibrosis, 14, 33. doi: 10.1016/S15691993(15)30105-3.

[7] Debray, D., Kelly, D., Houwen, R., Strandvik, B., \& Colombo, C. (2011) Best practice guidance for the diagnosis and management of cystic fibrosis-associated liver disease. Journal of Cystic Fibrosis, 10(2) S29-36. doi: 10.1016/S1569-1993(11)60006-4.

[8] Flass, T., \& Narkewicz, M. R. (2013). Cirrhosis and other liver disease in cystic fibrosis. Journal of Cystic Fibrosis, 12(2), 116-124. doi: 10.1016/j. jcf.2012.11.010.

[9] Ebdon, A. M., Nolan, S., Dick, K., Alexander, S., Bridges, N., \& Carr, S. B. (2014). Continuous glucose monitoring is a useful tool for diagnosis of cystic fibrosis related diabetes. Journal of Cystic Fibrosis, 13(2), S13. doi: https://doi.org/10.1016/S1569-1993(14)60042-4.

[10] Ali, B. R. (2009). Is cystic fibrosis-related diabetes an apoptotic consequence of ER stress in pancreatic cells? Med. Hypotheses, 72(1) 55-57. doi: 10.1016/j.mehy.2008.07.058.

[11] Minicucci, L. (2012). New diagnostic and therapeutic approaches in cystic fibrosis related diabetes (CFRD). Journal of Cystic Fibrosis, 7(6), 67-73.

[12] Flume, P. A., Mogayzel, P. J., Robinson, K. A., Goss, C. H., Rosenblat, R. L., Kuhn, R. J., et al. (2009). Cystic fibrosis pulmonary guidelines: treatment of pulmonary exacerbations. American journal of respiratory and critical care medicine, 180(9), 802-808. doi: 10.1164/ rccm.200812-1845PP.

[13] Schmid, K., Fink, K., Holl, R. W., Hebestreit, H., \& Ballmann, M. (2013). Predictors for future cystic fibrosis-related diabetes by oral glucose tolerance test. Journal of Cystic Fibrosis, 13(1), 80-85. doi: 10.1016/j. jcf.2013.06.001.

[14] Burgess, J. C., Bridges, N. Y., \& Simmonds, N. J. (2012). $1 . \quad$ Using $\mathrm{HbAlc}$ and random blood glucose to screen for cystic fibrosis related diabetes (CFRD). Journal of Cystic Fibrosis, 11(116), 56. 